\title{
THE ASSOCIATION OF OGG1 Ser326Cys POLYMORPHISM AND URINARY 8-OHdG LEVELS WITH LUING CANCER SUSCEPTIBILITY: A HOSPITAL- BASED CASE-CONTROL STUDY IN TURKEY
}

\author{
Bensu KARAHALIL ${ }^{1}$, Esra EMERCE ${ }^{1}$, Bülent KOÇER², Serdar HAN², Necati ALKIŞ \\ and Ali Esat KARAKAYA ${ }^{1}$
}

Gazi University, Faculty of Pharmacy, Department of Toxicology ${ }^{1}$, Ankara Numune Education and Research Hospital, Department of Thoracic Surgery², Ankara Oncology Education and Research Hospital, Department of Medical Oncology ${ }^{3}$, Ankara, Turkey

Received in October 2008

Accepted in November 2008

\begin{abstract}
High incidence and poor prognosis of lung cancer make it a major health problem worldwide. Although smoking is a major cause of lung cancer, only some smokers develop lung cancer, which suggests that there is a genetic predisposition in some individuals. 8-OHG is an important oxidative base lesion and may elevate due to cancer and smoking. It is repaired by 8-hydroxyguanine DNA glycosylase 1 (OGG1), which has several polymorphisms. Although the Ser326Cys polymorphism is consistently associated with a range of cancers, findings about this polymorphism and lung cancer risk are contradictory. To date, no study has examined this association in the Turkish population. We conducted a case-control study to investigate the association between OGG1 Ser326Cys polymorphism and the risk of lung cancer using PCR-RFLP. We also evaluated gene-smoking interaction and excretion of urinary 8-OHdG. Our results suggest that the OGG1 Ser326Cys polymorphism is not a genetic risk factor for lung cancer, and that the heterozygous genotype is associated with a significantly reduced risk for lung cancer. The levels of 8-OHdG did not correlate with the polymorphism and smoking. Larger association studies are needed to validate our findings, and mechanistic studies are needed to elucidate the underlying molecular mechanisms of this association.
\end{abstract}

KEY WORDS: disease, ELISA, genetic variation, oxidative stress, pharmacogenomic, RFLP

High incidence and poor prognosis of lung cancer make it a major health problem worldwide $(1,2)$. Lung cancer, which was initially considered an epidemic disease among men in industrialised nations, has now become the leading killer cancer in both sexes in the United States and an increasingly common disease of both sexes in developing countries (3).

In the Turkish population, it is the most common cancer in men and the sixth most common in women. Its incidence is 14.19 per 100,000 men and 1.24 per 100,000 women (4). While more than $80 \%$ of people who develop lung cancer are current or former smokers, only a small portion of smokers develop lung cancer, which suggests that there is a genetic predisposition in some individuals. To better understand the aetiology of this disease and more effectively target high-risk individuals in prevention and screening, it is important to identify factors that influence a smoker's risk of developing lung cancer (5).

Tobacco smoking which is the major cause of lung cancer, increases the rate of oxidative DNA damage (6), and tobacco smoke contains multiple carcinogens 
and reactive oxygen species (ROS) that are known to chemically modify DNA and lead to mutations. Accumulation of mutations in critical oncogenes and tumour suppressor genes promotes cancer $(7,8)$. Among many types of oxidative DNA damage, the 8hydroxyguanine (8-OHG) residue is one of the most abundant oxidative products of cellular DNA and is a mutagenic agent causing GC-to-TA transversions $(9$, 10). Increase in 8-OHG DNA content has been shown to elevate the cancer risk (11). It can be repaired by the activity of 8-hydroxyguanine DNA glycosylase 1 (OGG1), which catalyses the removal of 8-OHG by cleaving the $\mathrm{N}$-glycosyl bonds between the oxidised guanine and the deoxyribose backbone, leaving an apurinic/apyrimidinic site as an intermediate product (12). Studies on genetic structure have revealed the presence of several polymorphisms within the OGG1 locus (13). Among them, a C/G polymorphism at position 1245 in the $1 \alpha$-specific exon 7 of the OGG1 gene results in an amino acid substitution from serine to cysteine in codon 326 (14). It is not clear whether the amino acid substitution affects the catalytic properties of the enzyme, and limited knowledge is available on the association between cancer susceptibility and single nucleotide polymorphisms in this critical DNA repair gene $(15,16)$. In some studies, the OGG1 polymorphism Ser326Cys has been associated with increased risk of lung cancer. On the other hand, contradictory results have been reported about the association of the OGG1 Ser326Cys polymorphism and lung cancer risk for different populations. So far, however, there no such association has been studied in the Turkish population (17-22).

Among biomarkers used to identify cancer risk factors, p53 tumour suppressor gene mutations have been determined in several human cancers (23). It is well known that more than $50 \%$ of lung cancers carry a p53 mutation. The most common type of p53 mutation is the guanine $(G)$ to thymine (T) transversion (24), like OGG1. Furthermore, there are several distinct regions of frequent allele loss on chromosome 3p, indicating the presence of multiple tumour suppressor genes, including p53. Therefore, the OGG1 gene, located at 3p25 can be a strong tumor suppressor gene candidate (23) and partial or total loss of the mammalian Ogg1 proteins may predispose cells toward oncogenic transformation (25).

In our case-control study of the Turkish population, we wanted to see whether OGG1 Ser326Cys polymorphism was associated with susceptibility to lung cancer. Furthermore, gene-smoking status analyses were conducted to establish the geneenvironment interaction between OGG1 Ser326Cys polymorphism and cumulative cigarette smoking in lung cancer. We also evaluated urinary 8-hydroxy-2'deoxyguanosine (8-OHdG) as a marker of cellular oxidative stress in lung cancer patients who did not receive any radiotherapy and/or chemotherapy and in control subjects. We investigated whether there was any change in urinary 8-OHdG levels due to smoking and cancer.

\section{MATERIALS AND METHODS}

\section{Study Group}

We conducted a molecular epidemiologic casecontrol study that included 165 lung cancer patients (20 women and $145 \mathrm{men}$ ) and 250 control subjects (83 women, and 167 men). The age of control subjects ranged from 20 to 82 years $(53.2 \pm 0.75)$ and in lung cancer patients from 18 to 82 years $(56.99 \pm 0.79)$. Details are given in Table 1.

The lung cancer patients were from hospitalbased, case-control studies of lung cancer carried out in Turkey. They were recruited at two hospitals, and the study was approved by the ethical committee of the Ankara Numune and Ankara Oncology Education and Research Hospitals. According to histological subtypes, lung cancer patients were classified as small cell lung cancer (SCLC, $\mathrm{n}=38$ ) and non-small cell lung cancer (NSCLC, $n=120$ ). In general, the prevalence of NSCLC is significantly higher than the prevalence of SCLC. All cancer diagnoses (except for seven patients) were confirmed by histopathology and cytology. The histopathologic type was determined using the World Health Organization (WHO) lung tumour classification in clinical use during patient accrual.

We asked the subjects to fill out a self-administered questionnaire that included general characteristics (age, sex, and socio-demographic characteristics), personal and family medical history, and smoking and drinking habits. Smoking was much more prevalent among lung cancer patients ( $85.5 \%$ ) than in control subjects $(50.4 \%)$. All study participants signed an informed consent form and completed a detailed questionnaire about smoking habits.

\section{Sample collection}

Five milliitres of peripheral blood was collected in a sterile EDTA container (Sigma) via venipuncture 
Table 1 General characteristics of lung cancer patients and controls

\begin{tabular}{|c|c|c|c|c|c|c|c|}
\hline & & Controls & Patients & $\mathrm{p}$ & SCLC & NSCLC & $\mathrm{p}$ \\
\hline \multicolumn{2}{|c|}{ Age $($ mean $\pm \mathrm{SEM})$} & $53.19 \pm 0.75$ & $56.99 \pm 0.79$ & \multirow{8}{*}{$0.0001 *$} & $57.79 \pm 1.42$ & $56.58 \pm 0.98$ & \multirow{8}{*}{$>0.05$} \\
\hline \multirow{2}{*}{ Sex } & Women / N (\%) & $83(33.2)$ & $20(12.1)$ & & $6(15.8)$ & $14(11.7)$ & \\
\hline & Men / N (\%) & $167(66.8)$ & $145(87.9)$ & & $32(84.2)$ & $106(88.3)$ & \\
\hline \multicolumn{2}{|c|}{$\mathrm{BMI}($ mean $\pm \mathrm{SEM})$} & $27.16 \pm 0.29$ & $24.94 \pm 0.35$ & & $25.25 \pm 0.86$ & $24.87 \pm 0.38$ & \\
\hline \multirow{2}{*}{$\begin{array}{l}\text { Smoking } \\
\text { status } \\
\mathrm{N}(\%)\end{array}$} & Never & $121(48.4)$ & $24(14.5)$ & & $5(13.2)$ & $19(15.8)$ & \\
\hline & Smoker & $126(50.4)$ & $141(85.5)$ & & $33(86.8)$ & $101(84.2)$ & \\
\hline \multirow{2}{*}{$\begin{array}{l}\text { Smoker } \\
\mathrm{N}(\%)\end{array}$} & $\begin{array}{l}\leq 20 \text { cigarettes } \\
\text { per day }\end{array}$ & $80(62)$ & 70 (49.6) & & $20(60.6)$ & $47(46.5)$ & \\
\hline & $\begin{array}{l}>20 \text { cigarettes } \\
\text { per day }\end{array}$ & $26(20.2)$ & $64(45.4)$ & & $13(39.4)$ & $48(47.5)$ & \\
\hline
\end{tabular}

from each control subject and patient to determine OGG1 Ser326Cys polymorphism by PCR-RFLP. To detect urinary 8-OHdG levels $5-\mathrm{mL}$ spot urine samples were collected from 72 of 165 patients who had never received any chemotherapy and/or radiotherapy and from 61 of 250 control subjects. We could collect urine samples from only 80 controls and the sixtyone were age- and sex-matched to lung cancer patients. All blood and urine samples were stored at $-20{ }^{\circ} \mathrm{C}$ until analysis.

\section{DNA isolation and determination of OGG1 genotype}

DNA was extracted from whole blood using a sodium perchlorate / chloroform extraction method (9). We used a simple PCR-RFLP method (9) to identify the Ser326Cys variant, because the $C$ to $G$ transversion creates a new Fnu4HI restriction site. Briefly, the 207 bp fragment was amplified by PCR in a $30 \mu \mathrm{L}$ reaction volume that contained $100 \mathrm{ng}$ genomic DNA, $0.2 \mathrm{mmol} \mathrm{L}^{-1}$ of dNTP (Fermentas Life Sciences, Lithuania), $1.5 \mathrm{mmol} \mathrm{L}^{-1}$ of $\mathrm{MgCl}_{2}$ (Fermentas Life Sciences, Lithuania), 0.3 pmol of each primer and 1 unit of Taq DNA polymerase (Fermentas Life Sciences, Lithuania). The primers used for amplification of OGG1 gene exon 7, containing Ser326Cys, were 5'-ACT GTC ACT AGT CTC ACC AG-3' forward (lontek)and 5'-TGA ATT CGG AAG GTG CTT GGG GAA T-3' reverse(lontek). Cycling conditions were as follows: initial denaturation at $94^{\circ} \mathrm{C}$ for $2 \mathrm{~min}$, then amplification by 33 cycles of denaturation at $94{ }^{\circ} \mathrm{C}$ for $15 \mathrm{~s}$, annealing at $60{ }^{\circ} \mathrm{C}$ for $30 \mathrm{~s}$, and elongation at $72{ }^{\circ} \mathrm{C}$ for $35 \mathrm{~s}$, followed by extension at $72{ }^{\circ} \mathrm{C}$ for 10 min. The PCR product was digested with 3 units of Fnu4H1 (Fermentas, Lithuania) at $37^{\circ} \mathrm{C}$ for $16 \mathrm{~h}$, and then electrophoresed on a $6 \%$ polyacrylamide gel (Applichem). The Cys/Cys homozygote is cleaved by Fnu4HI, and yields 2 bands (100 bp and 107 bp bands). The Ser/Ser homozygote is not cleaved by FNU4HI, and the single 207 bp band remains. The Ser/Cys heterozygote contains all 3 bands (100 bp, $107 \mathrm{bp}$, and $207 \mathrm{bp}$ bands) following restriction digestion (26). Negative controls (no template) and positive controls were included in all sets.

\section{Detection of urinary 8-OHdG levels}

Stressgen's StressXpress DNA Damage ELISA (enzyme-linked immunosorbent assay) (Stressgen Bioreagents) is a fast and sensitive competitive immunoassay for the detection and quantitation of $8-\mathrm{OHdG}$ in spot urine samples. Measurement of urinary 8-OHdG is useful as an indicator of oxidative damage. Urine samples were diluted with sample diluents. We determined the optimal sample dilutions for our particular experiments to avoid being out of the range of the standard curve. Fifty microlitres of each prepared standard and samples were added to the wells of 8-OHdG immunoassay plate in duplicates, and then $50 \mu \mathrm{L}$ of diluted anti-8-OHdG was added into each well, except for the blank. The plate was 
incubated at room temperature for one hour, and the wells were washed using the wash buffer, and $100 \mu \mathrm{L}$ of diluted anti-Mouse IgG:HRP conjugate was added to each well, except for the blank. Again, the plate was incubated at room temperature for one hour, and the wells were washed using the wash buffer. One hundred microlitres of TMB substrate were added into each well and the plate was incubated at room temperature for 15 min in the dark. After adding $100 \mu \mathrm{L}$ acid stop solution into each well, absorbance was measured at $450 \mathrm{~nm}$. The standard curve was in the range of $0.94 \mathrm{ng} \mathrm{mL}^{-1}$ to $60 \mathrm{ng} \mathrm{mL}^{-1}$. The 8-OHdG calibration curve was plotted and 8-OHdG sample concentration was calculated. Urinary 8-OHdGper creatinine levels were expressed after correction for creatinine concentrations and presented as nmol per mmol creatinine.

\section{Statistical Analyses}

Data analysis was performed using SPSS for Windows, version 11.5. Shapiro-Wilk test was used in order to detect whether the continuous variables were normally distributed or not. Descriptive statistics were shown as mean \pm standard error for continuous data. The differences regarding continuous variables were evaluated using the Mann-Whitney $U$ test or KruskalWallis, according to the number of independent groups. When the p-value from the Kruskal-Wallis test was statistically significant, we applied the Kruskal Wallis multiple comparison tests to see which groups differed from which. Categorical comparisons were evaluated using the chi-square or Fisher's exact test, where applicable. Multiple logistic regression analysis was adjusted for age, sex, BMI, and smoking status. Odds ratio and $95 \% \mathrm{Cls}$ for each independent variable were calculated. The Bonferroni correction was applied for all possible within-group comparisons. A p value of less than 0.05 was considered statistically significant.

\section{RESULTS}

We tested the association between OGG1 Ser326Cys polymorphism and the risk of lung cancer in a population-based, case control study of 165 cases and 250 controls in the Turkish population. Among the lung cancer patients, $23 \%(n=38)$ were diagnosed SCLC, $72.7 \%(n=120)$ NSCLC, and the remaining $7.2 \%(n=7)$ were of unknown histological type. The subtypes of NSCLC were adenocarcinoma (25\%), squamous cell carcinoma (34.2\%), and $40.8 \%$ was unknown.

The allele frequency of the variant $G$ allele for OGG1 Ser326Cys was 0.28 for the lung cancer patients and 0.33 for controls. The prevalence of this polymorphism followed the Hardy-Weinberg equilibrium. The frequency distributions of alleles for OGG1 are shown in Table 2. To determine whether the OGG1 326Cys allele contributed to the increased risk of lung cancer, we compared the prevalence of OGG1 alleles in lung cancer patients and control subjects. The more common allele 326Ser was considered the reference genotype, whereas the less common allele 326Cys was examined as the variant. ORs were adjusted for age, sex, BMI, and smoking status. There was no association between the polymorphism in OGG1 Ser326Cys and the risk of lung cancer (OGG1 Ser326Cys $\mathrm{OR}_{\mathrm{adj}}=0.87$; $95 \% \mathrm{Cl}=0.551-1.36$; $\mathrm{p}=0.531$ and OGG1 Cys326Cys $\mathrm{OR}_{\mathrm{adj}}=0.59 ; 95 \%$ $\mathrm{Cl}=0.283-1.235 ; \mathrm{p}=0.162$ ).

The contribution of the OGG1 Ser326Cys polymorphism in each histological sub-type is shown in Table 3. To assess whether OGG1 Ser326Cys polymorphism was associated with histological sub-types of the lung cancer, cases were stratified according to tumour histological classification. When stratified by histology, a significant decrease in risk was observed in SCLC sub-group for Ser326Cys genotype. However, it was no longer significant when the groups were adjusted for age, sex, and smoking. No association was observed between NSCLC and the OGG1 Ser326Cys polymorphism. The OGG1 polymorphism did not significantly alter lung cancer risk by sex $(p<0.05$ in the crude and adjusted analysis). This suggests that sex is not the confounder of lung cancer risk.

Table 2 Association between the OGG1 genotypes and lung cancer risk

\begin{tabular}{lcccccc}
\hline Genotype & Controls & Patients & $\begin{array}{c}\text { Crude OR } \\
\text { (CI 95 \%) }\end{array}$ & p & $\begin{array}{c}\text { Adjusted OR } \\
\text { (CI 95 \%) }\end{array}$ & P \\
\hline Ser/Ser & $115(4)$ & $\mathbf{n}(\%)$ & 1 & & 1 & \\
\hline Ser/Cys & $106(42.4)$ & $65(52.1)$ & $0.82(0.541-1.244)$ & 0.35 & $0.87(0.551-1.36)$ & 0.531 \\
\hline Cys/Cys & $29(11.6)$ & $14(8.5)$ & $0.65(0.322-1.295)$ & 0.218 & $0.59(0.283-1.235)$ & 0.162 \\
\hline
\end{tabular}


Table 3 Association between the OGG1 Ser326Cys polymorphisms and lung cancer risk, stratified by histology and sex

\begin{tabular}{|c|c|c|c|c|c|c|c|c|}
\hline & & Genotype & $\begin{array}{c}\text { Controls } \\
\mathrm{n}(\%)\end{array}$ & $\begin{array}{c}\text { Patients } \\
\mathrm{n}(\%) \\
\end{array}$ & $\begin{array}{l}\text { Crude OR } \\
\text { (CI 95\%) }\end{array}$ & $p$ & $\begin{array}{l}\text { Adjusted OR } \\
\text { (CI 95\%) }\end{array}$ & p \\
\hline \multirow{6}{*}{$\begin{array}{l}\text { Histological } \\
\text { sub-types }\end{array}$} & \multirow{3}{*}{$\begin{array}{l}\text { SCLC } \\
(n=38)\end{array}$} & Ser/Ser & $115(46)$ & $25(65.8)$ & 1 & & 1 & \\
\hline & & Ser/Cys & $106(42.4)$ & $10(26.3)$ & $0.43(0.199-0.946)$ & $0.036^{*}$ & $0.56(0.232-1.331)$ & 0.188 \\
\hline & & Cys/Cys & $29(11.6)$ & $3(7.9)$ & $0.48(0.134-1.686)$ & 0.25 & $0.55(0.145-2.078)$ & 0.378 \\
\hline & \multirow{3}{*}{$\begin{array}{l}\text { NSCLC } \\
(n=120)\end{array}$} & Ser/Ser & $115(46)$ & $59(49.2)$ & 1 & & 1 & \\
\hline & & Ser/Cys & $106(42.4)$ & $50(41.7)$ & $0.92(0.580-1.456)$ & 0.72 & $1.01(0.602-1.683)$ & 0.980 \\
\hline & & Cys/Cys & 29 (11.6) & $11(9.2)$ & $0.74(0.345-1.584)$ & 0.437 & $0.68(0.299-1.542)$ & 0.355 \\
\hline \multirow{6}{*}{ Sex } & \multirow{3}{*}{ Women } & Ser/Ser & 37 (44.6) & $10(50)$ & 1 & & 1 & \\
\hline & & Ser/Cys & $36(43.4)$ & $9(45)$ & $0.93(0.337-2.541)$ & 0.880 & $0.92(0.335-2.548)$ & 0.878 \\
\hline & & Cys/Cys & $10(12)$ & $1(5)$ & $0.37(0.42-3.244)$ & 0.369 & $0.37(0.042-3.269)$ & 0.371 \\
\hline & \multirow{3}{*}{ Men } & Ser/Ser & 78 (46.7) & $76(52.4)$ & 1 & & 1 & \\
\hline & & Ser/Cys & $70(41.9)$ & $56(38.6)$ & $0.82(0.512-1.317)$ & 0.413 & $0.84(0.503-1.404)$ & 0.507 \\
\hline & & Cys/Cys & $19(11.4)$ & $13(9)$ & $0.70(0.324-1.521)$ & 0.370 & $0.65(0.288-1.474)$ & 0.304 \\
\hline
\end{tabular}

The analysis of potential interaction between the OGG1 polymorphism and cigarette smoking on the risk of lung cancer (Table 4) showed no association between the OGG1 Ser326Cys polymorphism and lung cancer risk regarding to smoking status. Furthermore, variant genotypes were not individual risk factors in light smokers ( $<20$ cigarettes per day). On the other hand, OGG1 variant genotypes were inversely associated with the risk of lung cancer in subjects who smoked more than 20 cigarettes per day, suggesting the protective effect of the genotype in heavy smokers.

We also measured the levels of urinary 8-OHdG as a biomarker of oxidative DNA damage in urine samples from 72 lung cancer patients (13 women, 59 men) who did not receive any chemotherapy and radiotherapy as well as in 61 (age and sex matched) control subjects (17 women, 44 men). The mean age of lung cancer patients and controls did not significantly differ (mean \pm SEM; $56.50 \pm 1.30$ years vs. $54.84 \pm 1.38$ years, $p>0.05$ ). Mean BMI of the control subjects was higher than in the lung cancer patients $(\mathrm{p}<0.05)$.

Table 5 shows the levels of urinary 8-OHdG in lung cancer and control subjects according to sex, age, smoking status, and histological sub-types. There was no significant difference in the levels of urinary 8-OHdG between the lung cancer patients and control subjects. Neither sex nor age contributed (the subjects were grouped by age; $\leq 60$ and $>60$ years) to the levels of urinary 8-OHdG levels in either lung cancer patients or controls. Our data showed that smoking

Table 4 Association between the OGG1 Ser326Cys polymorphisms and lung cancer risk according to smoking status

\begin{tabular}{|c|c|c|c|c|c|c|c|c|}
\hline & & \multirow{2}{*}{ Genotype } & Controls & Patients & \multirow{2}{*}{$\begin{array}{l}\text { Crude OR } \\
(\mathrm{CI} 95 \%)\end{array}$} & \multirow{2}{*}{$P$} & \multirow{2}{*}{$\begin{array}{l}\text { Adjusted OR } \\
\text { (CI } 95 \%)\end{array}$} & \multirow[b]{2}{*}{$\mathrm{p}$} \\
\hline & & & $\mathrm{n}(\%)$ & $\mathrm{n}(\%)$ & & & & \\
\hline \multirow{6}{*}{$\begin{array}{l}\text { Smoking } \\
\text { status }\end{array}$} & \multirow{3}{*}{ Never } & Ser/Ser & $55(45.5)$ & $12(50)$ & 1 & & 1 & \\
\hline & & Ser/Cys & $55(45.5)$ & $11(45.8)$ & $0.92(0.373-2.253)$ & 0.85 & $0.87(0.349-2.166)$ & 0.764 \\
\hline & & Cys/Cys & $11(9)$ & $1(4.2)$ & $0.42(0.049-3.542)$ & 0.423 & $0.41(0.048-3.55)$ & 0.419 \\
\hline & \multirow{3}{*}{ Smoker } & Ser/Ser & $59(46.8)$ & $74(52.5)$ & 1 & & 1 & \\
\hline & & Ser/Cys & $49(38.9)$ & $54(38.3)$ & $0.88(0.524-1.472)$ & 0.623 & $0.84(0.487-1.464)$ & 0.547 \\
\hline & & Cys/Cys & $18(14.3)$ & $13(9.2)$ & $0.58(0.261-1.270)$ & 0.172 & $0.62(0.266-1.431)$ & 0.26 \\
\hline \multirow{6}{*}{ Smokers } & \multirow{3}{*}{$\begin{array}{l}\leq 20 \\
\text { cigarettes } \\
\text { per day }\end{array}$} & Ser/Ser & $37(46.3)$ & $33(47.1)$ & 1 & & 1 & \\
\hline & & Ser/Cys & 33 (41.2) & $32(45.7)$ & $1.09(0.553-2.137)$ & 0.808 & $1.11(0.543-2.266)$ & 0.777 \\
\hline & & Cys/Cys & $10(12.5)$ & $5(7.2)$ & $0.56(0.174-1.809)$ & 0.333 & $0.76(0.218-2.668)$ & 0.671 \\
\hline & \multirow{3}{*}{$\begin{array}{l}>20 \\
\text { cigarettes } \\
\text { per day }\end{array}$} & Ser/Ser & $9(34.6)$ & $38(59.4)$ & 1 & & 1 & \\
\hline & & Ser/Cys & $11(42.3)$ & $18(28.1)$ & $0.39(0.136-1.101)$ & 0.075 & $0.30(0.095-0.939)$ & $0.039 *$ \\
\hline & & Cys/Cys & $6(23.1)$ & $8(12.5)$ & $0.32(0.87-1.140)$ & 0.078 & $0.22(0.055-0.915)$ & $0.037^{*}$ \\
\hline
\end{tabular}


Table 5 The effect of 8-OHdG excretion (nmol mmol-1 of creatinine) according to demographic characteristics

\begin{tabular}{|c|c|c|c|c|c|c|c|c|}
\hline \multirow[b]{2}{*}{ Groups } & & \multicolumn{3}{|c|}{ Controls } & \multicolumn{3}{|c|}{ Lung cancer patients } & \multirow[b]{2}{*}{$\mathrm{p}^{* *}$} \\
\hline & & $\mathrm{n}$ & $\begin{array}{c}\text { 8-OHdG / } \\
\text { nmol mmol }{ }^{-1} \\
\text { mean } \pm \text { SEM }\end{array}$ & $\mathrm{p}$ & $\mathrm{n}$ & $\begin{array}{c}\text { 8-OHdG } / \\
\text { nmol mmol }^{-1} \\
\text { mean } \pm \text { SEM }\end{array}$ & $\mathrm{p}$ & \\
\hline Total & & 61 & $70.03 \pm 7.11$ & & 72 & $67.26 \pm 5.63$ & & 0.946 \\
\hline \multirow{2}{*}{ Sex } & Women: & 17 & $65.46 \pm 11.65$ & \multirow{2}{*}{0.987} & 13 & $66.90 \pm 13.40$ & \multirow{2}{*}{0.878} & 0.967 \\
\hline & Men: & 44 & $71.80 \pm 8.83$ & & 59 & $67.34 \pm 6.26$ & & 0.920 \\
\hline \multirow{2}{*}{ Age } & $<60$ year & 39 & $67.25 \pm 8.05$ & \multirow{2}{*}{0.928} & 43 & $59.74 \pm 6.27$ & \multirow{2}{*}{0.230} & 0.659 \\
\hline & $\geq 60$ year & 22 & $74.96 \pm 13.82$ & & 29 & $78.41 \pm 10.24$ & & 0.834 \\
\hline \multirow{3}{*}{$\begin{array}{l}\text { Smoking } \\
\text { status }\end{array}$} & Never & 35 & $63.81 \pm 8.65$ & \multirow{3}{*}{0.337} & 18 & $66.68 \pm 9.67$ & \multirow{3}{*}{0.700} & 0.523 \\
\hline & Former & 15 & $77.32 \pm 11.33$ & & 29 & $69.52 \pm 8.65$ & & 0.480 \\
\hline & Current & 11 & $79.90 \pm 24.43$ & & 25 & $65.06 \pm 10.99$ & & 0.919 \\
\hline \multirow{2}{*}{$\begin{array}{l}\text { Histological } \\
\text { sub-types }\end{array}$} & SCLC & 61 & $70.03 \pm 7.11$ & & 10 & $89.05 \pm 15.97$ & \multirow{2}{*}{0.124} & 0.173 \\
\hline & NSCLC & 61 & $70.03 \pm 7.11$ & & 61 & $63.93 \pm 6.04$ & & 0.619 \\
\hline
\end{tabular}

$p^{* *}$ : Statistical analysis between lung cancer patients and controls

had no effect on the levels of urinary 8-OHdG in either group ( $p>0.05)$. Furthermore, control 8-OHdG levels did not significantly differ from those in SCLC or NSCLC patients.

In this study, we further investigated the association between urinary 8-OHdG levels and OGG1 Ser326Cys polymorphism (Table 6) and found that the excretion of 8-OHdG was not associated with the OGG1 Ser326Cys polymorphism. In lung cancer patients, there was no effect of the OGG1 Ser326Cys polymorphism on the levels of urinary 8-OHdG. On the other hand, in the control subjects, urinary 8-OHdG levels of subjects with the Ser326Ser genotype were found to be higher than in subjects with the Ser326Cys $(p=0.006)$ and Cys326Cys $(p=0.008)$ genotypes. However, no difference was observed between variant genotypes $(p=0.179)$. Our data demonstrated that the urinary 8-OHdG excretion was not affected by the OGG1 Ser326Cys polymorphism in respect to smoking.

Table 6 Effect of the OGG1 Ser326Cys genotypes on the levels of urinary 8-OHdG (nmol mmol-1 of creatinine)

\begin{tabular}{|c|c|c|c|c|c|c|c|c|c|}
\hline & & \multirow[b]{2}{*}{ Genotype } & \multicolumn{3}{|c|}{ Controls } & \multicolumn{3}{|c|}{ Patients } & \multirow[b]{2}{*}{$\mathrm{p}^{* *}$} \\
\hline & & & $\mathrm{n}$ & $\begin{array}{c}\text { 8-OHdG / } \\
\text { nmol mmol }^{-1} \\
\text { mean } \pm \text { SEM }\end{array}$ & $\mathrm{p}$ & $\mathrm{n}^{\#}$ & $\begin{array}{c}\text { 8-OHdG / } \\
\text { nmol mmol }^{-1} \\
\text { mean } \pm \text { SEM }\end{array}$ & $\mathrm{p}$ & \\
\hline \multirow{3}{*}{\multicolumn{2}{|c|}{ Total }} & Ser/Ser & 26 & $87.65 \pm 11.35$ & \multirow{3}{*}{$0.015^{*}$} & 33 & $65.96 \pm 9.28$ & \multirow{3}{*}{0.860} & 0.079 \\
\hline & & Ser/Cys & 31 & $59.50 \pm 9.28$ & & 24 & $67.01 \pm 8.14$ & & 0.186 \\
\hline & & Cys/Cys & 4 & $37.12 \pm 21.08$ & & 7 & $82.05 \pm 24.52$ & & 0.648 \\
\hline \multirow{9}{*}{$\begin{array}{l}\text { Smoking } \\
\text { status }\end{array}$} & \multirow{3}{*}{ Never } & Ser/Ser & 16 & $83.46 \pm 14.69$ & \multirow{3}{*}{$0.036 \bullet$} & 9 & $53.61 \pm 12.83$ & \multirow{3}{*}{0.606} & 0.207 \\
\hline & & Ser/Cys & 15 & $49.96 \pm 9.78$ & & 5 & $70.73 \pm 14.92$ & & 0.197 \\
\hline & & Cys/Cys & 4 & $37.12 \pm 21.08$ & & 1 & 158.79 & & \\
\hline & \multirow{3}{*}{ Former } & Ser/Ser & 5 & $78.98 \pm 18.00$ & \multirow{3}{*}{0.859} & 13 & $72.23 \pm 14.23$ & \multirow{3}{*}{0.955} & 0.703 \\
\hline & & Ser/Cys & 10 & $76.49 \pm 15.08$ & & 12 & $69.70 \pm 13.52$ & & 0.674 \\
\hline & & Cys/Cys & 0 & 0 & & 2 & $64.43 \pm 20.51$ & & \\
\hline & \multirow{3}{*}{ Current } & Ser/Ser & 5 & $109.74 \pm 33.41$ & \multirow{3}{*}{0.126} & 11 & $68.65 \pm 20.32$ & \multirow{3}{*}{0.919} & 0.267 \\
\hline & & Ser/Cys & 6 & $55.03 \pm 34.23$ & & 7 & $59.74 \pm 13.35$ & & 0.101 \\
\hline & & Cys/Cys & 0 & 0 & & 4 & $71.67 \pm 38.16$ & & \\
\hline
\end{tabular}

$n^{\#}$ : no genotype data for 8 lung cancer subjects

$p^{* *}$ : statistical analysis between lung cancer patients and controls

$\bullet:$ not significant according to Bonferroni correction( $p>0.025)$ 


\section{DISCUSSION}

Oxidative DNA damage is believed to be implicated in lung carcinogenesis. The potential mechanism of carcinogenesis in the lung tissue may involve tissue damage and regeneration in the presence of a high ROS release from inflammatory cells that can interact with DNA in epithelial cells to produce permanent genomic mutations (27). One of them, 8-OHG is a mutagenic and most common oxidative modification of guanine, and has a pivotal role in the development of lung cancer. Base excision repair (BER) is a highly conserved essential mechanism for maintaining genome integrity. Impaired BER function can give rise to the accumulation of 8-OHG lesion and other DNA base lesions, which may influence the initiation and progression of cancer (28). OGG1 is a key enzyme in short-patch BER because it recognises and performs initial excision of the most common form of oxidative DNA base damage, 8-OHG (29). OGG1 encodes an 8-oxoguanine DNA glycosylase/AP lyase that catalyzes the removal of 8-OHG from DNA (30). There are many polymorphisms found in the OGG1 gene. The most studied is the single nucleotide polymorphism at codon 326 (Ser326Cys). Homozygous carriers of the variant form of the OGG1 Ser326Cys gene appear to have reduced repair capacity for oxidised DNA lesions $(31,32)$, but this association has not been found in all investigations (33).

Epidemiological studies of the OGG1 Ser326Cys polymorphism in relation to cancer have yielded mixed results with a weak association between the OGG1 Ser326Cys genotype and the risk of lung cancer (18, 33-35). Since there have been contradictory findings so far, we conducted a case-control study of 165 lung cancer cases and 250 controls using PCR-RFLP method to identify the Ser326Cys and a questionnaire approach to investigate its association with lung cancer risk and possible interaction with smoking. We found that the distribution of the OGG1 Ser326Cys genotypes in controls (Ser/Ser, $46.0 \%$; Ser/Cys, $42.4 \%$; and $\mathrm{Cys} / \mathrm{Cys} 11.6 \%$ ) did not significantly differ from lung cancer patients $(52.1 \%, 39.4 \%$, and $8.5 \%$, respectively) ( $>>0.05)$. No statistically significant associations between the OGG1 Ser326Cys polymorphism and lung cancer risk were observed. Our results are similar to Wikman et al. and some other authors (19, 36-38). Wikman et al. carried out a case-control study to investigate the association between the OGG1 Ser326Cys polymorphism and the risk of lung cancer. They found no major difference in
Ser326Cys genotype distribution between lung cancer patients and controls and suggested the studied hOGG1 polymorphisms were probably not major contributors to individual lung cancer susceptibility in Caucasians (19). Hung et al. also observed that there were no such associations between them $(36,37)$.

Sorensen et al. examined the associations between polymorphism and the intake of fruits and vegetables and smoking in the development of lung cancer in 431 lung cancer patients and 796 controls. They found no overall association between the OGG1 polymorphism and lung cancer (38). Vogel et al. did not find any association between the polymorphisms OGG1 Ser326Cys and the risk of lung cancer (37). Sugimura et al. found that the Ser326Cys polymorphism was not associated with an increased risk of lung cancer in any subtypes; however, when homozygous Cys326Cys were compared with other genotypes in combination, an increased risk was observed for the squamous cell carcinoma and nonadenocarcinoma after adjustment for age and smoking (17). On the other hand, Ito et al. did not find any effects of the OGG1 Ser326Cys polymorphism on the development of either adenocarcinomas or small cell carcinoma (39). In our study, we found a significant decrease in the risk of SCLC for the Ser326Cys genotype, but this significance disappeared after adjusting for age, sex, and smoking. A reduced cancer risk associated with the OGG1 Ser326Cys polymorphism, as found in our study, has previously been reported by De Ruyck et al. (22). We believe that this may be due to an adaptive response with alternative pathyways. Thus, proteins that play an important role in other repair pathways (NER), especially NEIL1 and MUTYH proteins, may be involved in the repair and prevention of 8oxodG-derived mutations and may be up-regulated by oxidative stress in subjects with the Ser326Cys polymorphism. Furthermore, NEIL1 is able to excise lesions where OGG1 has very limited activity.

We could not find any modifying effect of smoking combined with the OGG1 Ser326Cys polymorphism that may contribute to lung cancer development. The OR for smoking was not statistically different across the genotypes, but the sample size was too small to detect even a moderate interaction. Our results corroborate the findings by Ito et al. (39). Additional studies, especially on mRNA expression levels, need to be conducted to confirm this association.

In this study, there was no difference between lung cancer patients and control subjects in the levels of urinary 8-OHdG. Our results are similar to Loft et 
al. (40) and Erhola et al.(41). Increased 8-OHdG excretion in controls indicates that their repair capacity is more effective than in the lung cancer patients.

Accumulating evidence seems to support the association between the OGG1 Ser326Cys polymorphism and smoking-related cancers, but the small sample size in our study and the presence of many conflicting data call for further studies on the association between the OGG1 Ser326Cys polymorphism and lung cancer, especially for studies that would include the smoking status in different populations with larger sample sizes. In conclusion, the OGG1 Ser326Cys polymorphism cannot explain individual variation in lung cancer susceptibility in humans. Future studies that investigate the mRNA expression, the activity of OGG1 protein, DNA repair capacity and excretion of DNA repair products are required to better understand the role of DNA damage in lung cancer.

\section{Acknowledgement}

This study was supported by Gazi University Scientific Research Foundation of Turkey (Project No: 02/2006-12)

\section{Conflict of Interest Statement}

The authors declare that they have no competing financial interests.

\section{REFERENCES}

1. Minna JD, Roth JA, Gazdar AF. Focus on lung cancer. Cancer Cell 2002;1:149-52.

2. Howe HL, Wingo PA, Thun MJ, Ries LA, Rosenberg H, Feigal E, Edwards BK. Annual report to the nation on the status of cancer (1973 through 1998), featuring cancers with recent increasing trends. J Natl Cancer Inst 2001;93:824-42.

3. Bilello KS, Murin S, Matthay RA. Epidemiology, etiology, and prevention of lung cancer. Clin Chest Med 2002;23:1-25.

4. Turkish Ministry of Health. Cancer statistics according to years 1999 [displayed 28 April 2007] available at http://www.saglik.gov.tr/TR/BelgeGoster.aspx?F6E10 F8892433CFF71BE64510F6C8BC92747D9FFFE7 A1226.

5. Littman AJ, Thornquist MD, White E, Jackson LA, Goodman GE, Vaughan TL. Prior lung disease and risk of lung cancer in a large prospective study. Cancer Causes Control 2004;15:819-27.
6. Loft S, Poulsen HE. Cancer risk and oxidative DNA damage in man. J Mol Med 1997;75:67-8.

7. Eva Y, Lee HP. Tumor suppressor genes: a new era for molecular genetic studies of cancer. Breast Cancer Res Treat 1991;19:3-13.

8. Hoffmann H, Isner C, Högel J, Speit G. Genetic polymorphisms and the effect of cigarette smoking in the comet assay. Mutagenesis 2005;20:359-64.

9. Karahalil B, Kocabas NA. OGG1 Ser326Cys genetic polymorphism in a Turkish population. Arch Toxicol 2005;79:377-80.

10. David SS. Structural biology: DNA search and rescue. Nature 2005;434:569-70.

11. Kasai $\mathrm{H}$. Analysis of a form of oxidative DNA damage 8-hydroxy-2'-deoxyguanosine, as a marker of cellular oxidative stress during carcinogenesis. Mutat Res 1997;387:147-63.

12. Karahalil B, Hogue BA, de Souza-Pinto NC, Bohr VA. Base excision repair capacity in mitochondria and nuclei: tissue-specific variations. FASEB $\mathrm{J}$ 2002;16:1895-902.

13. Xing DY, Tan W, Song N, Lin DX. Ser326Cys polymorphism in OGG1 gene and risk of esophageal cancer in a Chinese population. Int J Cancer 2001;95:140-3.

14. Kohno T, Shinmura K, Tosaka M, Tani M, Kim S, Sugimura H, Nohmi T, Kasai H, Yokota J. Genetic polymorphisms and alternative splicing of the OGG1 gene, that is involved in the repair of 8-hydroxyguanine in damaged DNA. Oncogene 1998;16:3219-25.

15. Vogel U, Olsen A, Wallin H, Overvad K, Tjonneland A, Nex BA. No Association between OGG1 Ser326Cys and Risk of Basal Cell Carcinoma. CEBP 2004;13:16801.

16. Xu J, Zheng SL, Turner A, Isaacs SD, Wiley KE, Hawkins GA, Chang BL, Bleeckeri ER, Walsh PC, Meyers DA, Isaacs WB. Associations between OGG1 sequence variants and prostate cancer susceptibility. Cancer Res 2002;62:2253-7.

17. Sugimura H, Kohno T, Wakai K, Nagura K, Genka K, Igarashi H, Morris BJ, Baba S, Ohno Y, Gao C, Li Z, Wang J, Takezaki T, Tajima K, Varga T, Sawaguchi T, Lum JK, Martinson JJ, Tsugane S, Iwamasa T, Shinmura K, Yokota J. OGG1 Ser326Cys polymorphism and lung cancer susceptibility. CEBP 1999;8:669-74.

18. Kohno T, Sakiyama T, Kunitoh H, Goto K, Nishiwaki Y, Saito D, Sasaki-Matsumura R, Mimaki S, Toyama K, Yamamoto S, Kuchiba A, Sobue T, Ohta T, Ohki M, Yokota J. Association of polymorphisms in the MTH1 gene with small cell lung carcinoma risk. Carcinogenesis 2006;27:2448-54.

19. Wikman H, RischA, Klimek F, Schmezer P, Spiegelhalder B, Dienemann H, Kayser K, Schulz V, Drings P, Bartsch H. OGG1 polymorphism and loss of heterozygosity ( $\mathrm{LOH})$ : Significance for lung cancer susceptibility in a caucasian population. Int J Cancer 2000;88:932-7. 
20. Lan Q, Mumford JL, Shen M, DeMarini DM, Bonner MR, He X, Yeager M, Welch R, Chanock S, Tian L, Chapman RS, Zheng T, Keohavong P, Caporaso N, Rothman N. Oxidative damage-related genes AKR1C3 and OGG1 modulate risks for lung cancer due to exposure to $\mathrm{PAH}$-rich coal combustion emissions. Carcinogenesis 2004;25:2177-81.

21. Marchand LL, Donlon F, Lum-Jones A, Seifried A, Wilkens LR. Association of the OGG1 Ser326Cys polymorphism with lung cancer risk. CEBP 2002;11:409-12.

22. De Ruyck K, Szaumkessel M, De Rudder I, Dehoorne A, Vral A, Claes K, Velghe A, Van Meerbeeck J, Thierens H. Polymorphisms in base-excision repair and nucleotideexcision repair genes in relation to lung cancer risk. Mutation Res 2007;631:101-10.

23. Forgacs E, Zöchbauer-Müller S, Olah E, Minna JD. Molecular genetic abnormalities in the pathogenesis of human lung cancer. Pathol Oncol Res 2001;7:6-13.

24. Hussain SP, Haris CC. Molecular epidemiology of human cancer: Contribution of mutation spectra studies of tumor suppressor genes. Cancer Res 1998;58:4023-37.

25. Lu R, Nash HM, Verdine GL. A mammalian DNA repair enzyme that excises oxidatively damaged guanines maps to a locus frequently lost in lung cancer. Current Biol 1997;7:397-407.

26. Karahalil B, Kocabas NA, Ozcelik T. DNA repair gene polymorphism and bladder cancer susceptibility in a Turkish population. Anticancer Res 2006;26:4955-8.

27. Park J, Chen L, Tockman MS, Elahi A, Lazarus P. The human 8-oxoguanine DNA N-glycosylase 1 (OGG1) DNA repair enzyme and its association with lung cancer risk. Pharmacogentics 2003;14:103-9.

28. Zhang Y, Newcomb PA, Egan KM, Titus-Ernstoff L, Chanock S, Welch R, Brinton LA, Lissowska J, BardinMikolajczak A, Peplonska B, Szeszenia-Dabrowska N, Zatonski W, Garcia-Closas M. Genetic polymorphisms in base-excision repair pathway genes and risk of breast cancer. CEBP 2006;2:353-8.

29. Nock NL, Cicek MS, Li L, Liu X, Rybicki BA, Moreira A, Plummer SJ, Casey G, Witte JS. Polymorphisms in estrogen bioactivation, detoxification and oxidative DNA base excision repair genes and prostate cancer risk. Carcinogenesis 2006;27:1842-8.

30. Rossner P, Terry MB, Gammon MD, Zhang FF, Teitelbaum SL, Eng SM, Sagiv SK, Gaudet MM, Neugut AI, Santella RM. OGG1 Polymorphisms and breast cancer risk. CEBP 2006;15:811-5.

31. Smart DJ, Chipman JK, Hodges NJ. Activity of OGG1 variants in the repair of pro-oxidant-induced 8-oxo-2'deoxyguanosine. DNA Repair 2006;5:1337-45.
32. Vodicka P, Stetina R, Polakova V, Tulupova E, Naccarati A, Vodickova L, Kumar R, Hanova M, Pardini B, Slyskova J, Musak L, De PG, Soucek P, Hemminki K. Association of DNA repair polymorphisms with DNA repair functional outcomes in healthy human subjects. Carcinogenesis 2006;28:657-64.

33. Janssen K, Schlink K, Gotte W, Hippler B, Kaina B, Oesch F. DNA repair activity of 8-oxoguanine DNA glycosylase 1 (OGG1) in human lymphocytes is not dependent on genetic polymorphism Ser326/Cys326. Mutation Res 2001;486:207-16.

34. Hung RJ, Hall J, Brennan P, Boffetta P. Genetic polymorphisms in the base excision repair pathway and cancer risk: a huge review. Am J Epidemiol 2005; 162:925-42.

35. Paz-Elizur T, Krupsky M, Blumenstein S, Elinger D, Schechtman E, Livneh Z. DNA repair activity for oxidative damage and risk of lung cancer. J Natl Cancer Inst 2003;95:1312-9.

36. Hung RJ, Brennan P, Canzian F, Szeszenia-Dabrowska N, Zaridze D, Lissowska J, Rudnai P, Fabianova E, Mates D, Foretova L, Janout V, Bencko V, Chabrier A, Borel S, Hall J, Boffetta P. Large-scale investigation of base excision repair genetic polymorphisms and lung cancer risk in a multicenter study. J Natl Cancer Inst 2005;97:567-76.

37. Vogel U, Nexø BA, Wallin H, Overvad K, Tjønneland A, Raaschou-Nielsen O. No association between base excision repair gene polymorphisms and risk of lung cancer, Biochem Genet 2004;42:453-60.

38. Sørensen M, Raaschou-Nielsen O, Hansen RD, Tjønneland A, Overvad K, Vogel U. Interactions between the OGG1 Ser326Cys polymorphism and intake of fruit and vegetables in relation to lung cancer. Free Radic Res 2006;40:885-91.

39. Ito H, Hamajima N, Takezaki T, Matsuo K, Tajima K, Hatooka S, Mitsudomi T, Suyama M, Sato S, Ueda RA. Limited association of OGG1 Ser326Cys polymorphism for adenocarcinoma of the lung. $\mathrm{J}$ Epidemiol 2002;12:258-65.

40. Loft S, Svoboda P, Kasai H, Tjønneland A, Vogel U, Moller P, Overvad K, Raaschou-Nielsen O. Prospective study of 8-oxo-7,8-dihydro-20-deoxyguanosine excretion and the risk of lung cancer. Carcinogenesis 2006;27:1245-50.

41. Erhola M, Toyokuni S, Okada K, Tanaka T, Hiai H, Ochi H, Uchida K, Osawa T, Nieminen MM, Alho $\mathrm{H}$, Kellokumpu-Lehtinen P. Biomarker evidence of DNA oxidation in lung cancer patients: association of urinary 8-hydroxy-2'-deoxyguanosine excretion with radiotherapy, chemotherapy, and response to treatment. FEBS Letters 1997;409:287-91. 


\section{Sažetak}

POVEZANOST OGG1 Ser326Cys POLIMORFIZMA I RAZINA 8-OHdG U MOKRAĆI SA SKLONOSTI OBOLIJEVANJU OD KARCINOMA PLUĆA: REZULTATI ISPITIVANJA NA BOLESNICIMA I KONTROLNOJ POPULACIJI U TURSKOJ

Karcinom pluća velik je javnozdravstveni problem u čitavom svijetu zbog svoje visoke učestalosti i loše prognoze. Premda je navika pušenja jedan od glavnih uzročnika karcinoma pluća, od ove bolesti oboli samo dio populacije pušača, što govori u prilog postojanju genetske predispozicije za njezin nastanak. 8-OHG je oksidativno oštećenje baze u molekuli DNA čija se učestalost može povećati zbog zloćudnih tumora i pušenja. U popravku tog oštećenja sudjeluje enzim 8-hidroksigvanin DNA-glikozilaza (OGG1) za koji je dokazano postojanje polimorfizma. lako se polimorfizam Ser326Cys često dovodi u vezu s različitim vrstama zloćudnih bolesti, dosadašnji su rezultati o vezi između polimorfizma tog enzima i rizika od pojave karcinoma pluća kontradiktorni. Do danas na turskoj populaciji nisu provedena istraživanja koja bi dala jasne odgovore o toj povezanosti. Ovo je istraživanje usporedo provedeno u bolesnika i u zdravoj populaciji primjenom metode PCR-RFLP s ciljem utvrđivanja moguće povezanosti polimorfizma OGG1 Ser326Cys i rizika od karcinoma pluća. Nadalje, istražena je interakcija gena i navike pušenja te ekskrecija 8-OHdG u mokraći. Dobiveni rezultati pokazuju da polimorfizam OGG1 Ser326Cys nije genetski čimbenik rizika od pojave karcinoma pluća, a pokazalo se da je heterozigotni genotip povezan sa značajno nižim rizikom od karcinoma pluća. Razine 8-OHdG izmjerene u mokraći nisu bile u korelaciji ni s polimorfizmom ni s navikom pušenja. Zaključujemo da su za vrednovanje dobivenih rezultata potrebna istraživanja na još većem broju ispitanika te mehanistička istraživanja koja bi mogla razjasniti molekularne mehanizme koji su u pozadini ove povezanosti.

KLJUČNE RIJEČI: bolest, ELISA, farmakogenomika, genetska varijacija, oksidatiuni stres, RFLP

\section{CORRESPONDING AUTHOR:}

\section{Professor Bensu Karahalil}

Gazi University, Faculty of Pharmacy

Department of Toxicology

06330, Hipodrom, Ankara, Turkey

E-mail: bensuka@gmail.com 